\title{
ONE STRAIN-MANY COMPOUNDS (OSMAC) METHOD FOR PRODUCTION OF PHENOLIC COMPOUNDS USING Camarops sp., AN ENDOPHYTIC FUNGUS FROM Alibertia macrophylla (Rubiaceae) $)^{*}$
}

\author{
Juliana R. Gubiania, Thomas R. Habecka, Vanessa M. Chapla ${ }^{\mathrm{b}}$, Geraldo H. Silva ${ }^{\mathrm{c}}$, Vanderlan S. Bolzania, and Angela R. \\ Araujo $^{\mathrm{a}, *}$ \\ aDepartamento de Química Orgânica, Instituto de Química, Universidade Estadual Paulista, 14800-900 Araraquara - SP, Brasil. \\ ${ }^{b}$ Colegiado de Ciências Exatas e Biotecnológicas, Universidade Federal de Tocantins, 77402-970 Gurupi - TO, Brasil. \\ 'Instituto de Ciências Exatas e Tecnológica, Universidade Federal de Viçosa, 38810-000 Rio Paranaíba - MG, Brasil.
}

Recebido em 10/05/2016; aceito em 26/06/2016; publicado na web em 20/09/2016

\begin{abstract}
ONE STRAIN-MANY COMPOUNDS (OSMAC) METHOD FOR PRODUCTION OF PHENOLIC COMPOUNDS USING Camarops sp., AN ENDOPHYTIC FUNGUS FROM Alibertia macrophylla (RUBIACEAE). Seven phenolic derivatives including $p$-hydroxyphenyllactic acid (1), $p$-hydroxybenzoic acid (2), $p$-hydroxybenzaldehyde (3), phenyllactic acid (4), $n$-butyl-3,4dihydroxybenzoate (5), $n$-hexyl-3,4-dihydroxybenzoate (6) and n-octyl-3,4-dihydroxybenzoate (7) were produced using Camarops sp. via the one strain-many compounds (OSMAC) approach. Their structures were determined using 2D NMR and ESI-MS spectra and were compared with works reported in the literature. This paper deals with the first report of these compounds in Camarops sp.
\end{abstract}

Keywords: endophytic fungus; Camarops sp.; phenolic compounds

\section{INTRODUCTION}

Endophytic fungi are a diverse group of organisms ubiquitous in plants and found to maintain an imperceptible association with their hosts for at least a part of their life cycle. ${ }^{1}$ These fungi present an enormous ability when it comes to the production of a wide range of new bioactive metabolites from a single strain through the systematic alteration of the cultivation parameters, known as the OSMAC (one strain many compounds) approach. The OSMAC mechanism came into being thanks to the observation that small changes in the cultivation conditions were capable of completely altering the metabolic profile of many microorganisms. Thus, the mechanism is considered a powerful tool which can contribute meaningfully towards elucidating the secondary metabolome of different microbes. ${ }^{2}$

In our recent work, Camarops sp. was cultivated in corn where it was found to produce a broad range of eremophilane sesquiterpenes, with antioxidant, anti-inflammatory and cytotoxic activities besides the potent inhibitory activity that was observed against the proteases subtilisin and pepsin., ${ }^{3,4}$ To further explore its potential in the production of secondary metabolites, the OSMAC approach was applied aiming at maximizing the chemical diversity of this fungus. Our present work seeks to report the isolation and characterization of the aforementioned seven phenolic derivatives: $p$-hydroxyphenyllactic acid (1), p-hydroxybenzoic acid (2), p-hydroxybenzaldehyde (3), phenyllactic acid (4), n-butyl-3,4- dihydroxybenzoate (5), $n$ -hexyl-3,4-dihydroxybenzoate (6) and $n$-octyl-3,4- dihydroxybenzoate (7) (Figure 1).

*e-mail: araujoar@iq.unesp.br

aNuBBE - Núcleo de Bioensaios, Biossíntese e Ecofisiologia de Produtos Naturais.

\#This paper is part of the PubliSBQ Special Issue in honor of the late Prof Angelo da Cunha Pinto.

\section{EXPERIMENTAL SECTION}

\section{General experimental procedures}

${ }^{1} \mathrm{H}$ NMR (500 MHz), ${ }^{13} \mathrm{C}$ NMR (125 MHz), HMBC, HSQC and COSY experiments were conducted in a Varian INOVA-500 spectrometer using the residual non-deuterated (DMSO- $\mathrm{d}_{6}$ ) signal as an internal standard. Mass spectra were measured using a Thermo Scientific ${ }^{\mathrm{TM}}$ LCQ Fleet ${ }^{\mathrm{TM}}$ ion trap mass spectrometer set to ESI mode with $\mathrm{MeOH}: \mathrm{H}_{2} \mathrm{O}$ (1:1) being the solvent (cone voltage $25 \mathrm{~V}$ ). TLC analyses were performed using Merck silica gel 60 (230 mesh) and precoated silica gel $60 \mathrm{PF}_{254}$. Spots on the TLC plates were visualized either under UV light or by spraying with anisaldehyde- $\mathrm{H}_{2} \mathrm{SO}_{4}$ reagent followed by heating at $120^{\circ} \mathrm{C}$. Analytical and preparative HPLC were performed in a Shimadzu SPD-M20A system using Phenomenex Luna $\mathrm{C}_{18}$ column (250 mm x $\left.4.6 \mathrm{~mm}, 5 \mu \mathrm{m}\right)$, Synergi Hydro Phenomenex ${ }^{\circledR} \mathrm{C}_{18}$ column $(250 \mathrm{~mm}$ x $21.2 \mathrm{~mm}, 4 \mu \mathrm{m})$, Supelcosil Supelco ${ }^{\circledR} \mathrm{C}_{18}$ column $(250 \mathrm{~mm}$ x $21.2 \mathrm{~mm}, 12 \mu \mathrm{m})$ and Luna Phenomenex ${ }^{\circledR} \mathrm{C}_{18}$ column (150 mm x $\left.21.2 \mathrm{~mm}, 5 \mu \mathrm{m}\right)$. Column chromatography (CC) was carried out over reversed-phase silica gel, 230-400 mesh (Merck).

\section{Plant material}

Authenticated Alibertia macrophylla K. Schum. (Rubiaceae) was collected from the Mogi-Guaçu Experimental Ecology Station, at Campininha Farm, Mogi-Guaçu, São Paulo, Brazil, in November 2003. Dr. Inês Cordeiro from Institute of Botany, São Paulo, was responsible for the identification of A. macrophylla and a voucher specimen was stored at the Herbarium of the Institute of Botany of São Paulo, Brazil (Voucher no SP 370915).

\section{Fungal isolation and identification}

The endophytic fungus Camarops sp. was isolated according to the previously described procedure. ${ }^{5}$ The pure fungal strain was stored as Camarops sp. at the NuBBE fungi collection in Araraquara, Brazil (kept in sterile water at $25^{\circ} \mathrm{C}$ ). ${ }^{6}$ The pure Camarops sp. culture was 
sent to the Microbial Resources Division, Multidisciplinary Research Center of Agricultural and Biological Chemistry, State University of Campinas (CPQBA/UNICAMP), and was classified by Drs. Lara Durães Sette and André Rodrigues. ${ }^{4}$

\section{Cultivation and isolation of Camarops sp. metabolites}

The endophytic fungus strain Camarops sp. was cultivated in $19500 \mathrm{~mL}$ Erlenmeyer flasks, each containing $300 \mathrm{~mL}$ of Czapek's liquid medium of sterilized $\mathrm{H}_{2} \mathrm{O}$. The medium was autoclaved at $121{ }^{\circ} \mathrm{C}$ for $40 \mathrm{~min}$. Following sterilization, the medium was in turn inoculated with the endophyte and incubated while stationary at $25^{\circ} \mathrm{C}$ for 28 days. The mycelia biomass accumulated in the Erlenmeyers flasks was separated from the aqueous medium by filtration, and the filtrate was subjected to a liquid-liquid partition with EtOAc $(3 \times 2.5 \mathrm{~L})$. The EtOAc fraction was evaporated deriving in the EtOAc crude extract $(0.845 \mathrm{~g})$, which was fractionated by $\mathrm{C}_{18}$ RPCC and eluted with $\mathrm{H}_{2} \mathrm{O}-\mathrm{CH}_{3} \mathrm{OH}$ 90:10 (210 mL), 85:15 (210 mL), 80:20 (210 mL), 75:25 (210 mL), 70:30 (210 mL), 60:40 (210 mL), 50:50 $(210 \mathrm{~mL}), 40: 60(210 \mathrm{~mL})$ and $100 \% \mathrm{CH}_{3} \mathrm{OH}(210 \mathrm{~mL})$, giving rise to eight fractions (Fr1-Fr8). Fraction Fr2 (496 mg) was diluted in $\mathrm{H}_{2} \mathrm{O}(500 \mathrm{~mL})$ and subjected to a liquid-liquid partition with EtOAc $(3 \times 250 \mathrm{~mL})$. The EtOAc was evaporated resulting in the EtOAc subfraction Fr2 (96.4 mg), and was further separated by HPLC using $\mathrm{C}_{18}$ Synergi Hydro Phenomenex ${ }^{\circledast}$ column $(4 \mu \mathrm{m}, 21.2 \mathrm{~mm}$ x $250 \mathrm{~mm})$ and $\mathrm{H}_{2} \mathrm{O}: \mathrm{CH}_{3} \mathrm{OH} 85: 15$ as eluent for $60 \mathrm{~min}$ at $10.0 \mathrm{~mL} / \mathrm{min}$, leading to 6 subfractions (Fr2-A-Fr2-F). The subfraction Fr2-C was identified as compound $\mathbf{1}\left(5.7 \mathrm{mg}, \mathrm{R}_{\mathrm{t}}=27.0\right.$ at $\left.35.0 \mathrm{~min}\right)$. Additionally, the subfraction Fr2-D was identified as compounds $\mathbf{2}$ and $\mathbf{3}$ (4.5 mg, $\mathrm{R}_{\mathrm{t}}=36.0$ at $55.0 \mathrm{~min}$ ) while Fr2-E as compounds $\mathbf{4}$ and $\mathbf{5}(11.4 \mathrm{mg}$, $\mathrm{R}_{\mathrm{t}}=56.0$ at $\left.60.0 \mathrm{~min}\right)$. Fraction $\mathrm{Fr} 3(72.7 \mathrm{mg})$ was further separated by HPLC using $\mathrm{C}_{18}$ Supelcosil Supelco ${ }^{\circledR}$ column $(12 \mu \mathrm{m}, 21.2 \mathrm{~mm}$ x $250 \mathrm{~mm}$ ) and $\mathrm{H}_{2} \mathrm{O}: \mathrm{CH}_{3} \mathrm{OH} 75: 25$ as eluent for $60 \mathrm{~min}$ at $10.0 \mathrm{~mL} /$ min, generating 5 subfractions (Fr3-A-Fr3-E). Subfraction Fr3-C was identified as compounds $\mathbf{4}$ and $\mathbf{5}\left(17.1 \mathrm{mg}, \mathrm{R}_{\mathrm{t}}=8.5\right.$ at $\left.9.5 \mathrm{~min}\right)$ while Fr3-E as compound $\mathbf{4}\left(3.8 \mathrm{mg}, \mathrm{R}_{\mathrm{t}}=10.5\right.$ at $\left.12.5 \mathrm{~min}\right)$. The subfraction Fr3-D (34.7 mg) was purified by HPLC using Luna Phenomenex ${ }^{\circledR} \mathrm{C}_{18}$ column $(5 \mu \mathrm{m}, 21.2 \mathrm{~mm} \times 150 \mathrm{~mm})$ and $\mathrm{H}_{2} \mathrm{O}: \mathrm{CH}_{3} \mathrm{OH} 30: 70$ as eluted for $25 \mathrm{~min}$ at $10.0 \mathrm{~mL} / \mathrm{min}$, giving rise to 2 subfractions (Fr3-D-1Fr3-D-2). The subfraction Fr3-D-1 was identified as compounds 4 and 5 (4.0 $\mathrm{mg}, \mathrm{R}_{\mathrm{t}}=3.0$ at $\left.8.0 \mathrm{~min}\right)$ while Fr3-D-2 as compounds $\mathbf{5}$, 6 and $7\left(2.0 \mathrm{mg}, \mathrm{R}_{\mathrm{t}}=20.0\right.$ at $\left.25.0 \mathrm{~min}\right)$.

\section{RESULTS AND DISCUSSION}

Through the application of the OSMAC method, the EtOAc crude extract was derived from the cultivation of Camarops sp. in Czapek's liquid medium from which seven compounds were obtained. The compounds were identified as $p$-hydroxyphenyllactic acid $(\mathbf{1})^{7,8}, p$-hydroxybenzoic acid $(2)^{8,9}, p$-hydroxybenzaldehyde $(3)^{10}$, phenyllactic acid (4) $)^{11}, n$-butyl-3,4-dihydroxybenzoate $(5)^{11,12}$, $n$-hexyl-3,4-dihydroxybenzoate $(\mathbf{6})^{11,12}$ and $n$-octyl-3,4-dihydroxybenzoate $(7)^{11,12}$ (Figure 1).

The NMR ${ }^{1} \mathrm{H}$ spectra of $p$-hydroxyphenyllactic acid (1) (Table 1) when analyzed along with HSQC data indicated the presence of two doublets $\left[\delta_{\mathrm{H}} 7.00\left(2 \mathrm{H}, J=8.2 \mathrm{~Hz}, \mathrm{H}-3\right.\right.$ and $\left.\mathrm{H}-5, \delta_{\mathrm{C}} 129.8\right)$ and 6.63 $\left(2 \mathrm{H}, J=8.2 \mathrm{~Hz}, \mathrm{H}-2\right.$ and $\left.\left.\mathrm{H}-6, \delta_{\mathrm{C}} 114.4\right)\right]$, with characteristic coupling constant for ortho-positioned hydrogen atoms, showing a disubstituted aromatic moiety. Furthermore, the presence of a methylene group $\left[\delta_{\mathrm{H}} 2.85\left(d l, J=12.8 \mathrm{~Hz}, 1 \mathrm{H}, \mathrm{H}-7, \delta_{\mathrm{C}} 39.3\right)\right.$, and $2.62(m, 1 \mathrm{H}, \mathrm{H}-7$, $\left.\delta_{\mathrm{C}} 39.3\right)$ ], implying the closeness of this hydrogen to a stereogenic center, in addition to the carbon chemical shift led us to conclude that it was a benzylic carbon. An oxygenated methine group $\left[\delta_{\mathrm{H}} 3.96(\mathrm{sl}\right.$,<smiles>[R]c1ccc(CC(O)C(=O)O)cc1</smiles><smiles>[R]OC(=O)c1ccc(O)c(O)c1</smiles><smiles>[R]c1ccc(O)cc1</smiles>

$5 \mathrm{R}=\left(\mathrm{CH}_{2}\right)_{3} \mathrm{CH}_{3}$ $\begin{aligned} 6 \mathrm{R} & =\left(\mathrm{CH}_{2}\right)_{5} \mathrm{CH}_{3} \\ 7 \mathrm{R} & =\left(\mathrm{CH}_{2}\right)_{7} \mathrm{CH}_{3}\end{aligned}$

$\mathrm{R}=\mathrm{COH}$

Figure 1. Compounds isolated from Camarops sp.

$\left.\left.2 \mathrm{H}, \mathrm{H}-8, \delta_{C} 71.4\right)\right]$ characteristic of a carbinolic hydrogen enabled the identification of a hydroxyl group directly bonded to carbon $\beta$ of an aromatic ring. The HMBC correlations between $\mathrm{H}-2 \leftrightarrow \mathrm{C}-1 / \mathrm{C}-3 / \mathrm{C}-4$, $\mathrm{H}-3 \leftrightarrow \mathrm{C}-2 / \mathrm{C}-5, \mathrm{H}-5 \leftrightarrow \mathrm{C}-2 / \mathrm{C}-3, \mathrm{H}-6 \leftrightarrow \mathrm{C}-1 / \mathrm{C}-3 / \mathrm{C}-4$ and $\mathrm{H}-7 \leftrightarrow \mathrm{C}-4$, confirmed the presence of carbonyl carbon and aromatic unit. The side chain was positioned at C-4 based on the values of chemical shifts and multiplicities of the signals of the aromatic ring signals (Table 1), leading to the identification of compound $\mathbf{1}$ as $p$-hydroxyphenyllactic acid. $^{7,8}$

The ${ }^{1} \mathrm{H}$ NMR spectra of $p$-hydroxybenzoic acid (2) (Table 1) when analyzed jointly with the HSQC data indicated seven carbons besides the presence of two doublets $\left[\delta_{\mathrm{H}} 7.76(2 \mathrm{H}, J=8.7 \mathrm{~Hz}, \mathrm{H}-3\right.$ and $\mathrm{H}-5$, $\left.\delta_{\mathrm{C}} 131.1\right)$ and $6.81\left(2 \mathrm{H}, J=8.7 \mathrm{~Hz}, \mathrm{H}-2\right.$ and $\left.\left.\mathrm{H}-6, \delta_{\mathrm{C}} 114.9\right)\right]$, bearing a characteristic coupling constant of a para hydrogen, depicting a disubstituted aromatic ring system. The analysis of HMBC showed correlations of $\mathrm{H}-2$ and $\mathrm{H}-6 \leftrightarrow \mathrm{C}-1 / \mathrm{C}-3$ and $\mathrm{H}-3$ and $\mathrm{H}-5 \leftrightarrow \mathrm{C}-2 / \mathrm{C}-3 / \mathrm{C}-7$ confirming structure 2 of $p$-hydroxybenzoic acid. ${ }^{8,9}$

$p$-hydroxybenzaldehyde (3) was obtained in the mixture with 4. The ${ }^{1} \mathrm{H}$ spectra of $\mathbf{3}$ (Table 1) when analyzed together with the HSQC data pointed out a similarity to compound $\mathbf{2}$, the difference observed being the presence of one singlet at $\delta_{\mathrm{H}} 9.79(\mathrm{H}-7)$, suggesting the existence of an aldehyde function. These data associated with the NMR of compound 2 and the carbon $\delta_{C} 190.8$ (C-7) in the HMBC data showed the reduction of $\mathrm{C}-7$ carboxylic acid to an aldehyde function, confirming the structure $\mathbf{3}$ of $p$-hydroxybenzaldehyde. ${ }^{10}$

Phenyllactic acid (4) was obtained in a mixture with compound 3. ${ }^{1} \mathrm{H}$ spectra of $\mathbf{4}$ (Table 1) when analyzed along with the HSQC data indicated a similarity with to compound $\mathbf{1}$, the difference observed being the aromatic ring which showed a monosubstituted ring. ${ }^{1} \mathrm{H}$ NMR spectra indicated the presence of five $\mathrm{sp}^{2}$ methine groups at a complex aromatic region in a multiplet form $\left[\delta_{\mathrm{H}} 7.23\right.$ ( $m, \mathrm{H}-1, \mathrm{H}-2, \mathrm{H}-3, \mathrm{H}-5, \mathrm{H}-6)]$. Compound $\mathbf{4}$ was thus identified as phenyllactic acid. ${ }^{11}$

The ${ }^{1} \mathrm{H}$ spectra of $n$-butyl-3,4-dihydroxybenzoate (5) (Table 1) when analyzed along with the HSQC data indicated the presence of three $\mathrm{sp}^{2}$ methine groups, showing a trisubstituted aromatic ring system $\left[\delta_{\mathrm{H}} 6.82\left(d, J=8.0 \mathrm{~Hz}, 1 \mathrm{H}, \delta_{\mathrm{C}} 117.7, \mathrm{H}-5\right), 6.98(d d, J=8.0\right.$ and $\left.2.0 \mathrm{~Hz}, 1 \mathrm{H}, \delta_{\mathrm{C}} 123.4, \mathrm{H}-6\right)$, and $7.17\left(d, J=2.0 \mathrm{~Hz}, 1 \mathrm{H}, \delta_{\mathrm{C}} 113.6\right.$, $\mathrm{H}-2)]$, three methylene group found to be oxygenated $\left[\delta_{\mathrm{H}} 4.30(t, J\right.$ $\left.=6.5 \mathrm{~Hz}, 2 \mathrm{H}, \delta_{\mathrm{C}} 64.8, \mathrm{H}-2^{\prime}\right), 1.72\left(m, \delta_{\mathrm{C}} 27.2, \mathrm{H}-3^{\prime}\right)$ and $1.37(m$, $\left.\left.\delta_{\mathrm{C}} 27.2, \mathrm{H}-4^{\prime}\right)\right]$ and one methyl group $\left[\delta_{\mathrm{H}} 0.91\left(t, J=7.0 \mathrm{~Hz}, 3 \mathrm{H}, \delta_{\mathrm{C}}\right.\right.$ $\left.\left.13.4, \mathrm{H}-5^{\prime}\right)\right]$. The HSQC correlations together with the HMBC correlations exhibited four quaternary carbons $\left[\delta_{\mathrm{C}} 112.6(\mathrm{C}-1) ; 149.6\right.$ (C-3); 153.0 (C-4) and $168.8\left(\mathrm{C}-1^{\prime}\right)$ ]. These data associated with the ${ }^{1} \mathrm{H}-{ }^{1} \mathrm{H}$ COSY correlations led to a trisubstituted aromatic ring with two hydroxyl groups (C-3 and C-4) and one conjugated carbonyl 
Table 1. ${ }^{1} \mathrm{H}$ - and ${ }^{13} \mathrm{C}$ NMR data for compounds 1-5 $\left(500 \mathrm{MHz}, \mathrm{CDCl}_{3}\right)$

\begin{tabular}{|c|c|c|c|c|c|c|c|c|c|c|c|c|c|c|}
\hline \multirow{2}{*}{ Position } & \multicolumn{2}{|l|}{1} & \multirow{2}{*}{ Position } & \multicolumn{2}{|l|}{2} & \multirow{2}{*}{ Position } & \multicolumn{2}{|l|}{3} & \multirow{2}{*}{ Position } & \multicolumn{2}{|l|}{4} & \multirow{2}{*}{ Position } & \multicolumn{2}{|l|}{5} \\
\hline & $\delta{ }^{1} \mathrm{H}$ & $\delta{ }^{13} \mathrm{C}$ & & $\delta{ }^{1} \mathrm{H}$ & $\delta{ }^{13} \mathrm{C}$ & & $\delta{ }^{1} \mathrm{H}$ & $\delta{ }^{13} \mathrm{C}$ & & $\delta{ }^{1} \mathrm{H}$ & $\delta^{13} \mathrm{C}$ & & $\delta{ }^{1} \mathrm{H}$ & $\delta{ }^{13} \mathrm{C}$ \\
\hline 1 & - & 155.7 & 1 & - & 161.6 & 1 & - & 163.3 & 1 & $7.23(\mathrm{~m})$ & 125.9 & 1 & - & 112.6 \\
\hline 2 & $6.63(d, 8.2)$ & 114.4 & 2 & $6.81(d, 8.7)$ & 114.9 & 2 & $7.75(d, 8.5)$ & 132.0 & 2 & $7.23(\mathrm{~m})$ & 127.8 & 2 & $7.17(d, 2.0)$ & 113.6 \\
\hline 3 & $7.00(d, 8.2)$ & 129.8 & 3 & $7.76(d, 8.7)$ & 131.1 & 3 & $6.92(d, 8.5)$ & 115.8 & 3 & $7.23(\mathrm{~m})$ & 129.3 & 3 & - & 149.6 \\
\hline 4 & - & 130.4 & 4 & - & 121.9 & 4 & - & 129.3 & 4 & - & 138.3 & 4 & - & 153.0 \\
\hline 5 & $7.00(d, 8.2)$ & 129.8 & 5 & $7.76(d, 8.7)$ & 131.1 & 5 & $6.92(d, 8.5)$ & 115.8 & 5 & $7.23(\mathrm{~m})$ & 129.3 & 5 & $6.82(d, 8.0)$ & 117.7 \\
\hline 6 & $6.63(d, 8.2)$ & 114.4 & 6 & $6.81(d, 8.7)$ & 114.9 & 6 & $7.75(d, 8.5)$ & 132.0 & 6 & $7.23(\mathrm{~m})$ & 127.8 & 6 & $6.98(d d, 2.0 ; 8.0)$ & 123.4 \\
\hline $7 \mathbf{a}$ & $2.62(\mathrm{~m})$ & 39.3 & 7 & - & 167.7 & 7 & $9.79(s)$ & 190.8 & 7 & $\begin{array}{l}2.75(d d ; 10.0 ; 5.0) \\
2.96(d d ; 10.0 ; 5.0)\end{array}$ & 40.0 & 1 ' & - & 168.8 \\
\hline $7 b$ & $2.85(d l, 12.8)$ & 39.3 & & & & & & & 8 & $4.11(d d ; 5.0 ; 5.0)$ & 71.1 & 2 ' & $4.30(t, 6.5)$ & 64.8 \\
\hline 8 & $3.96(s l)$ & 71.4 & & & & & & & 9 & - & 175.1 & 3 ' & $1.72(\mathrm{~m})$ & 27.2 \\
\hline 9 & - & 175.5 & & & & & & & & & & 4 ' & $1.37(\mathrm{~m})$ & 27.2 \\
\hline & & & & & & & & & & & & 5 , & $0.91(t, 7.0)$ & 13.4 \\
\hline
\end{tabular}

ester (C-1'), confirming structure 5 of $n$-butyl-3,4-dihydroxybenzoate. Oddly enough, though all the data as can be seen from our discussion above led us towards the proposed structure, the integration of $-\mathrm{CH}_{2}$ to the alkyl chain failed to be consistent with it. By so doing, a mass spectrum was obtained and thanks to that it was possible to detect the isomers 5-7, justifying the congruence of the ${ }^{1} \mathrm{H}$ NMR data recorded.

The structures of the esters 5-7 were confirmed by mass spectrometry (ESI-MS) which showed the presence of [M-H] ion peaks at $m / z, 209.23$ (n-butyl-3,4-dihydroxybenzoate); 237.19 ( $n$-hexyl-3,4-dihydroxybenzoate) and 265.27 (n-octyl-3,4-dihydroxybenzoate) (Figure 2). ${ }^{11,12}$

The data obtained from sequencing and BLAST analysis of the 28S rDNA showed that the isolated $A M-02$ had $95 \%$ sequence identity with several species within the genus Camarops (Ascomycota: Boliniales, Boliniaceae). Ecologically, Camarops spp. are considered wood-inhabiting fungi and are found in both temperate and tropical regions. Cultures of $A M-02$ form abundant white aerial mycelium with the reverse side of the colony becoming orange-brown over the passage of time. Camarops spp. are characterized by stromatic ascomata with brown ascospores. ${ }^{4}$

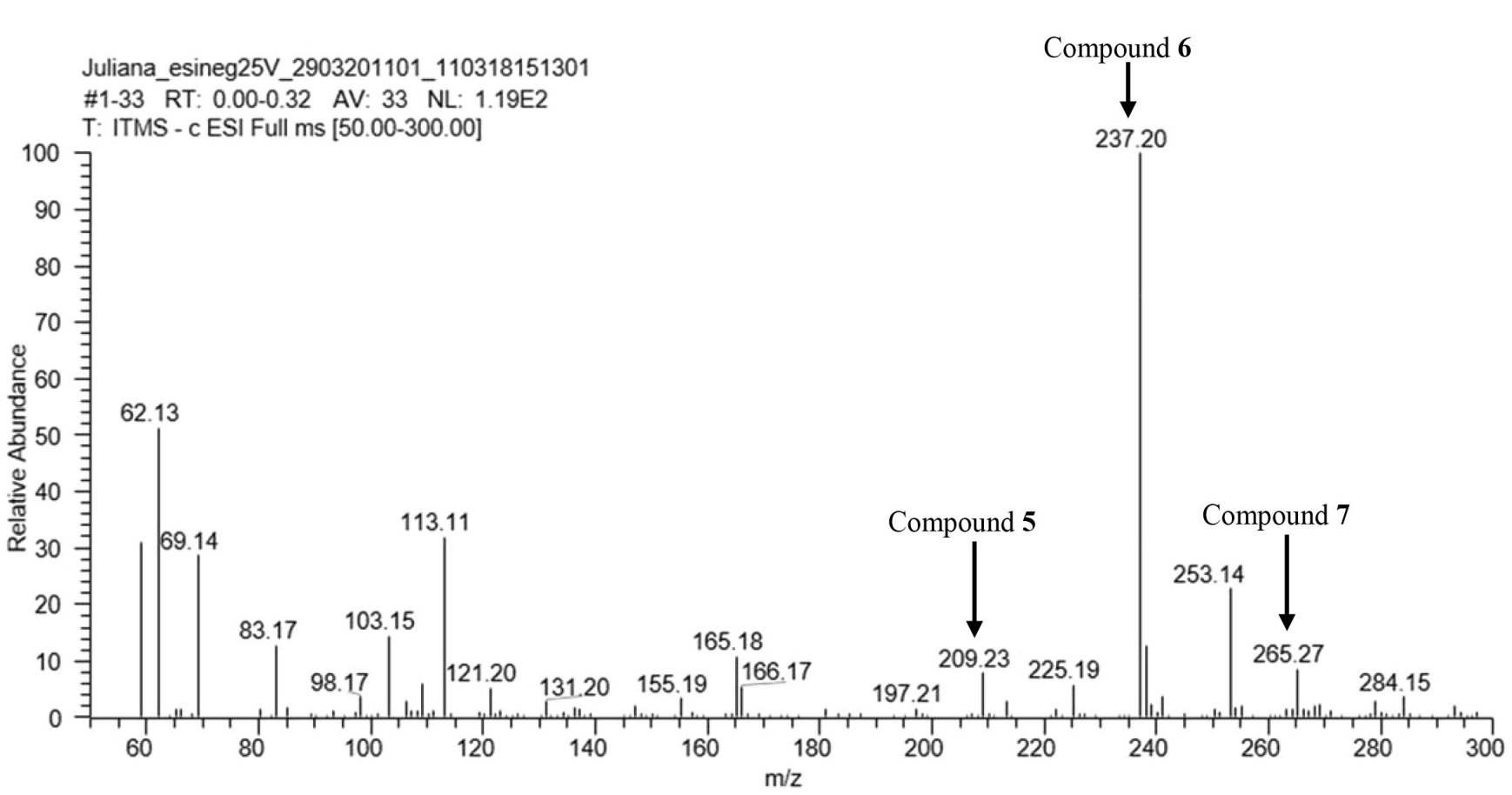

Nonetheless, upon cultivation in malt-extract agar, potato dextrose agar, and oat meal agar, the isolated $A M-02$ failed to produce ascomata and ascospores. Moreover, microscopic examination revealed thinwalled hyphae, though without the presence of asexual reproductive

Interestingly, the data derived from molecular and phylogenetic analyses suggest that the AM-O2 strain is related to Camarops species and as such there is a plausible likelihood that it represents a new taxon.

Phenolic compounds are known to be of indisputable importance owing to the fact that they are produced by plants or fungi in response to environmental stresses such as pathogens and insects attacks, UV radiation and wounds. They are found to be present in food consumed in human diet as well as in plants used in traditional medicine in many cultures. Some phenols are germicidal and as such are used in formulating disinfectants. Others are found to have anticancer, anti-inflammatory, antiviral, antibacterial, antioxidant and estrogenic activities while some present endocrine disruption.

Among the phenolic compounds, $p$-hydroxybenzoic acid (pHBA) (2) is known to play a vital role in three different sectors including structures. $^{4}$

Figure 2. Mass spectrum of compound 5 to 7 
the food, electronics and the pharmaceutical industries. In the food industry, it plays the role of an intermediate in the synthesis of red pigment shikonin. In addition, it acts as the main monomer in the production of LCPs (liquid crystal polymers) in the electronic industry. Finally, its role in the pharmaceutical industry is seen to be fundamentally crucial for the fact that it has significant antifungal activity. $P$-hydroxybenzoic acid is obtained by the Kolbe-Schmitt process under severe conditions of temperature and pressure, rendering the process, in effect, extremely costly in industrial scale. In light of that, endophytic fungi are becoming a financially more feasible alternative, considered environmentally renewable and sustainable when it comes to the production of large amounts of $p \mathrm{HBA}$.

\section{CONCLUSION}

The production of secondary metabolites by fungi is said to be dependent on both the biosynthetic capacity of the microorganisms and the fermentation conditions. In fact, based on our results, the manipulation of the fermentation process parameters is found to be capable of altering the expression of the secondary metabolites produced. Using this strategy, seven known compounds were isolated from Camarops sp. following the selection of their growth media composition.

The present study suggests that endophytic fungi are potentially suitable microorganisms for the OSMAC method, and could enhance the chemical diversity of secondary metabolites. This study reinforces the importance of using the OSMAC approach in the biosynthetic exploitation of endophytic fungi as our finding unravels a culture condition which induces this class of fungi towards the production of a wide range of phenolic compounds.

\section{ACKNOWLEDGMENTS}

The authors would like to express their sincerest gratitude and indebtedness to the Brazilian Research Funding Agencies - Fundação de Amparo à Pesquisa do Estado de São Paulo (FAPESP - grant process \# 2013/07600-3) and CNPq (process \# 563286/2010-5) for the funds granted in the course of this research. JRG, VMC and GHS are also extremely grateful to $\mathrm{CNPq}$ and CAPES for grating their
Ph.D. scholarships. Our thanks also go to the British native English language content editor - Brian Newmann for his painstaking editing and proofreading of the manuscript.

\section{REFERENCES}

1. Kusari, S.; Pandey, S. P.; Spiteller, M. Phytochemistry 2013, 91, 81.

2. Paranagama, P. A.; Wijeratne, E. M. K.; Gunatilaka, A. A. L. J. Nat. Prod. 2007, 70, 1939.

3. Gubiani, J. R.; Zeraik, M. L.; Oliveira, C. M.; Ximenes, V. F.; Nogueira, C. R.; Fonseca, L. M.; Silva, D. H. S.; Bolzani, V. S.; Araujo, A. R. J. Nat. Prod. 2014, 77, 668 .

4. Oliveira, C. M.; Silva, G. H.; Regasini, L. O.; Flausino; O.; López, S. N.; Abissi. B. M.; Berlinck, R. G. S.; Sette, L. D.; Bonugli-Santos, R. C.; Rodrigues, A.; Bolzani, V. S.; Araujo, A. R. J. Nat. Prod. 2011, 74, 1353.

5. Landecker, E. M. Fundamentals of the Fungi 4th ed.; Prentice Hall: NJ, 1996.

6. Silva, G. H.; Teles, H. L.; Zanardi, L. M.; Young, M. C. M.; Eberlin, M. N.; Haddad, R.; Pfenning, L. H.; Costa-Neto, C.; Castro-Gamboa, I.; Bolzani, V. S.; Araujo, A. R. Phytochemistry 2006, 67, 1964.

7. Arnone, A.; Assante, G.; Nasini, G.; Strada, S.; Vercesi, A. J. Nat. Prod. 2002, 65, 48; Lavermicocca, P.; Valerio, F.; Evidente, A. Lazzaroni, S.; Corsetti, A.; Gobbetti, M. Appl. Environ. Microb. 2000, 66, 4084.

8. Kambourova, R.; Petrov, G.; Bankova, V. Algol. Stud. 2006, 119, 155.

9. Zadernowski, R.; Naczk, M.; Nesterowicz, J. Agric. Food Chem. 2005, 53, 2118; Huang, Z.-J.; Yang, R.-Y.; Guo, Z.-Y.; She, Z.-G.; Lin, Y.-C. Chin. J. Appl. Chem. 2010, 27, 394; Armaforte, E.; Carri, S.; Ferri, G.; Caboni, M. F. J. Chromatogr. A 2006, 1131, 281; Yang, W.-Z.; Wang, H.; Shang, J.; Feng, F.; Xie, N. Chin. J. Nat. Med. 2009, 7, 193.

10. Wattanadilok, R.; Sawangwong, P.; Rodrigues, C.; Cidade, H.; Pinto, M.; Pinto, E.; Silva, A.; Kijjoa, A. Mar. Drugs 2007, 5, 40; Bell, A. A. Phytopathology 1970, 60, 161.

11. Lind, H.; Sjögren, J.; Gohil, S.; Kenne, L.; Schnürer, J.; Broberg, A. FEMS Microbiol. Lett. 2007, 271, 310; De Maria, C. A. B.; Moreira, R. F. A. Quím. Nova 2003, 26, 90.

12. Merkl, R.; Hrádková, I.; Filip, V.; Šmidrkal, J. Czech J. Food Sci. 2012, $28,275$. 